\title{
Oral Communication Skills of Engineering Students of Pakistan in Perspective of Industrial Internships
}

\author{
Inayatullah Kakepoto (Corresponding author) \\ Universiti Teknologi Malaysia, Faculty of Education, Johor Bahru, Johor, 81310 Malaysia \\ Quaid-e-Awam University of Engineering Science \& Technology Nawabshah 67480 (Sind) Pakistan \\ E-mail: inayat_kakepoto@yahoo.com
}

Hadina Habil

Universiti Teknologi Malaysia, Language Academy, Johor Bahru, Johor, 81310 Malaysia

Noor Abidah Mohd Omar

Universiti Teknologi Malaysia, Language Academy, Johor Bahru, Johor, 81310 Malaysia

Yusuf Boon

Universiti Teknologi Malaysia, Faculty of Education, Johor Bahru, Johor, 81310 Malaysia

Majid Hamdani

Universiti Teknologi Malaysia, Faculty of Education, Johor Bahru, Johor, 81310 Malaysia

Received: 30-05- 2012

Accepted: 20-06- 2012

Published: 01-07- 2012

doi:10.7575/ijalel.v.1n.2p.170

URL: http://dx.doi.org/10.7575/ijalel.v.1n.2p.170

\begin{abstract}
The purpose of this study was to determine impact of industrial internship training on oral communication skills of engineering students during this program. Fifty engineers from two engineering organizations participated in this study. Participants of this study had industrial internship training from different organizations. Purposive sampling method was used for data collection purpose. The results of the study revealed that industrial internship trainings contribute to develop oral communication skills of engineering students such as oral presentation skill, meeting skill, discussion skill, conversation skill, and project participation skill during this internship program. However, the results of this study are consistent with other literature review findings on industrial internship trainings for engineering students.
\end{abstract}

Keywords: Industrial internship training, oral communication skills, engineering students

\section{Background}

Industrial internships play paramount role for engineering graduates to perform workplace jobs effectively at workplace. Industrial internships play significant role to keep abreast engineering students about real world of work prior to joining the workplace. Industry demands from engineering graduates to be equipped with relevant workplace skills and knowledge in order to promote its business and increase its workplace productivity. In view of this, modern engineering graduates should acquire both technical and non technical skills such as communication, oral communication and presentation skills to be fit in this new millennium of organizations. Employers hire engineering graduates equipped with relevant work experience because engineering graduates equipped with industrial experience augment workplace productivity of organizations at a large measure. On the contrary, engineering graduates equipped with poor workplace skills and knowledge harm the interests of employers as well as organizations. Thus, employers usually ask this question from engineering graduates during job interviews whether they possess relevant work experience for the job applied for. Communication research demonstrates that engineering graduates equipped with internship experience perform better jobs compared to graduates who fall short in this experience.

Page $\mid 170$ 
International Journal of Applied Linguistics \& English Literature

ISSN 2200-3592 (Print), ISSN 2200-3452 (Online)

Vol. 1 No. 2; July 2012

Oral communication skills play significant role in the job career of an engineer. This is because modern engineering graduates have to perform diverse roles at workplace. They have to communicate with client and customers and other diverse people from public and private organizations on regular basis. Thus, these increased communications demand effective oral communication skills of engineering graduates to perform workplace jobs effectively and efficiently in this modern age of globalization and industrialization. Oral communication skills at workplace include oral presentation skill, meeting skill, discussion skill, conversation skill, and project participation skill. Oral presentation skill provides interns an idea how to present information for supervisors and managers relating to work they performed and barriers that confront them to perform that task. Meetings engage interns to formulate strategies in order to perform any specific task within stipulated framework of time. In addition, supervisor and managerial meetings provide interns an opportunity to obtain work related knowledge from supervisors and managers. On the other hand, workplace discussions develop better work relationship among interns, supervisors, managers, and other senior engineers working on managerial and non managerial positions. Moreover, conversation is a common mode of workplace communication. It contributes to develop oral communication skill of interns. This is because during conversations interns endeavour to obtain information not only from supervisors or managers but from other people who are closely related with that work. Project participations also develop oral communication skills of engineering students. This is because during project participation interns provide appropriate feedback regarding the project to be carried out by the organization. Thus, this participation and sharing of ideas contribute to develop oral communication skills of engineering students.

Internships have numerous benefits for engineering students. It fills the gap between classroom knowledge and practical knowledge (Mihail, 2006; Lam et al., 2007), because classroom knowledge is never sufficient for engineering students until and unless it is practiced practically in the field. In view of this, Engineering Accreditation Boards recommend at least six months internship trainings for engineering students prior to joining the workplace. Moreover, internships assist to modify engineering communication skills curriculum taught to engineering students. This is because there is urgent need for curriculum revision (Kofoworola, 2003), thus, academicians and employers should sit together to bring it at par with industry needs. Mills et al. (2003) illustrated that modern engineering graduates need to have strong communication skills but they don't have. In view of this, engineering graduates should acquire broad array of skills to be fit in this competitive work environment of organizations that demand effective oral communication skills of engineering graduates. If we analyze advantages of internships it benefits many stakeholders for instance industry, engineering universities, and engineering students (Gault et al., 2000). Employer benefits include selection of better future employees (Coco, 2000; Devine et al., 2007), university benefits include increased graduate employment (Divine et al., 2007), and curriculum assessment (Divine et al., 2007; Thiel \& Hartley, 1997) and student benefits include early job offers (Gault et al., 2008), good starting salaries (Coco, 2000; Gault et al., 2008 cited in Weible Rick, 2009), improved job related skills (Devine et al., 2007), interviewing skills (Gault, et al., 2008), and development of effective communication skills (Ellis, 2000; Mihail, 2006).

A study was conducted by Nizam et al., (2009) on assessment of engineering students' perception after industrial training placement. The results of the study supported the idea that internships develop communication skills of engineering students. Another study was conducted by Renganathan Sumathi et al. (2012) on students' perception of industrial internship program at Universiti Teknologi Petronas Malaysia. Respondents of this study were sought to provide feedback on 10 variables such as apply theoretical knowledge with practices in industry, acquire industry work culture, practice team work including multidisciplinary team, gain writing skills, develop oral or presentation skills, execute problem solving activities, develop managerial skills, appreciate the social and ethical responsibility, attain business insightfulness, aspire for future education and career after completion of internship training. For oral communication or presentation skills $81.4 \%$ respondents indicated that they developed oral communication or presentation skills during internship program. However, this study focuses on development of oral communication skills of engineering students in perspective of industrial internships. The findings of this study would contribute in the existing body of literature on industrial internships and oral communication skills of engineering students.

\section{Methodology}

This study employed quantitative approach based on questionnaire survey. This is because researcher could not manage interviews with engineers due to lack of time. Fifty engineers from 2 engineering organizations participated in this study. Purposive sampling method was used for data collection purpose because respondents were selected on specific criteria of maximum 3 years work experience. The rationale for selection of engineers with 3 years work experience was based on the understanding that these fresh engineers shall be better able to Page | 171 


\section{International Journal of Applied Linguistics \& English Literature}

ISSN 2200-3592 (Print), ISSN 2200-3452 (Online)

Vol. 1 No. 2; July 2012

provide appropriate feedback on advantages of internships and its impact on development of oral communication skills for engineering students. Singleton \& Straits (2005) illustrated that purposive sampling is a non probabilistic sampling method that is used for specific purpose.

Questionnaire administered to engineers contained two parts. First part of the questionnaire was related with demographics asking about gender, qualification, age, field of discipline, and work experience. Second part of this questionnaire contained statements relating to industrial internships and oral communication skills of engineering students. Data were analyzed quantitatively using Statistical Package for Social Sciences (SPSS). A 5 point likert scale ranging from 'strongly disagree' to 'strongly agree' was used to draw percentages for each dimension.

\section{Finding}

The findings of the study have been categorized into five headings for instance oral presentation skill, meeting skill, discussion skill, conversation skill, and project participation skill.

\subsection{Oral Presentation Skill}

When asked from engineers whether industrial internships contribute to develop oral presentation skill of engineering students $6 \%$ respondents strongly disagreed, $7 \%$ disagreed, $6 \%$ responded neutral, $62 \%$ agreed, while $19 \%$ strongly agreed that industrial internships play paramount role to augment oral presentation skill of engineering students.

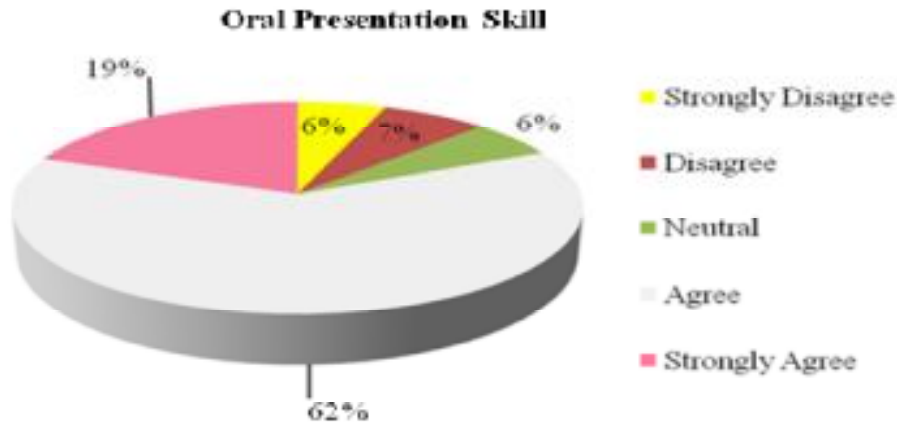

Figure 1. indicates respondents' level of agreement and disagreement for oral presentation skill Figure 1, shows agreement and disagreement level of respondents for oral presentation skill that industrial internships contribute to develop oral presentation skill of engineering students during industrial internships.

\subsection{Meeting Skill}

When asked from engineers whether industrial internships contribute to develop meeting skill of engineering students $7 \%$ engineers strongly disagreed, $11 \%$ disagreed, $10 \%$ responded neutral, $56 \%$ agreed; while $16 \%$ strongly agreed that industrial internships enhance meeting skill of engineering students to conduct meetings with supervisors and managers.

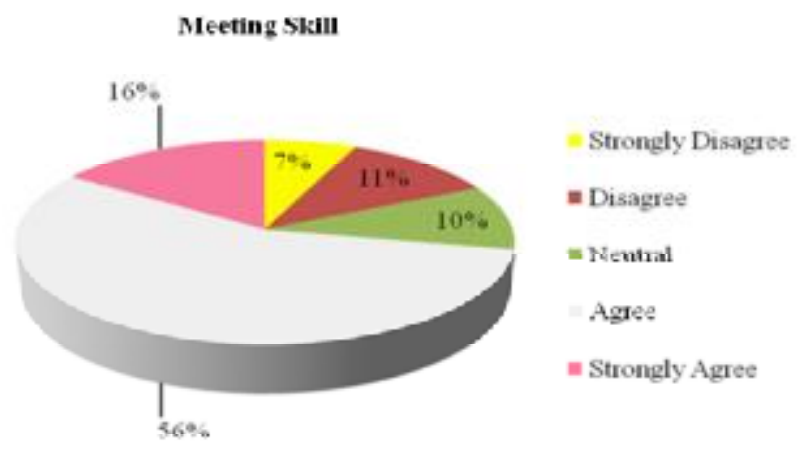

Figure 2. indicates respondents' level of agreement and disagreement for meeting skill

Page $\mid 172$ 


\section{International Journal of Applied Linguistics \& English Literature ISSN 2200-3592 (Print), ISSN 2200-3452 (Online)}

Vol. 1 No. 2; July 2012

Figure 2 indicates agreement and disagreement level for meeting skill that industrial internships contribute to develop meeting skill of engineering students during industrial internships.

\subsection{Discussion Skill}

When asked from engineers whether industrial internships contribute to develop discussion skill of engineering students $9 \%$ engineers strongly disagreed, $5 \%$ disagreed, $2 \%$ responded neutral, $70 \%$ agreed, while $14 \%$ strongly agreed that industrial internships increase discussion skill of engineering students.

\section{Discussion Skill}

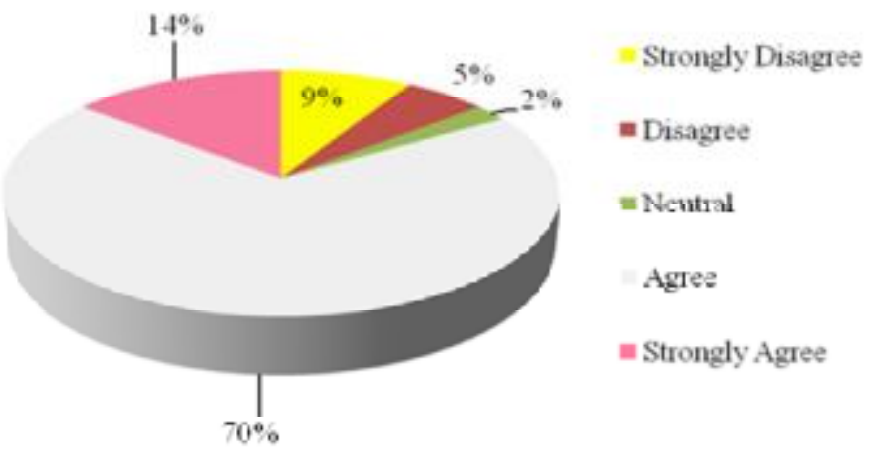

Figure 3. indicates respondents' level of agreement and disagreement for discussion skill

Figure, 3 shows agreement and disagreement level for discussion skill that industrial internships develop discussion skill of engineering students during industrial internships.

\subsection{Conversation Skill}

When asked from engineers whether industrial internships contribute to develop conversation skill of engineering students 5\% engineers strongly disagreed, $6 \%$ disagreed, $9 \%$ responded neutral, $53 \%$ agreed, while $27 \%$ strongly agreed that internships contribute to develop conversation skill of engineering students.

\section{ConversationSkill}

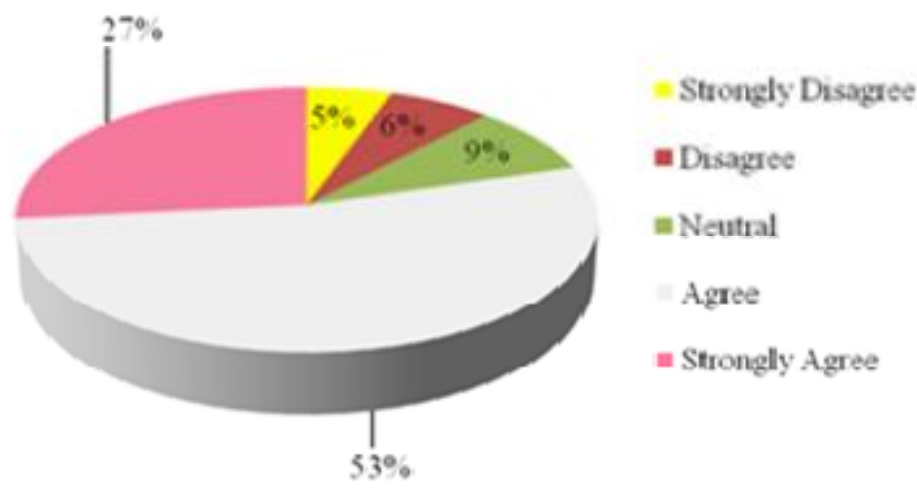

Figure 4. indicates respondents' level of agreement and disagreement for conversation skill 
International Journal of Applied Linguistics \& English Literature

ISSN 2200-3592 (Print), ISSN 2200-3452 (Online)

Vol. 1 No. 2; July 2012

Figure, 4 shows agreement and disagreement level for conversation skill that industrial internships develop conversation skill of engineering students during industrial internships.

\subsection{Project participation Skill}

When asked from engineers whether industrial internships contribute to develop project participation skill $9 \%$ engineers strongly disagreed, $10 \%$ disagreed, $9 \%$ responded neutral, $55 \%$ agreed, while $17 \%$ strongly agreed that industrial internships contribute to develop project participation skill of engineering students.

\section{Project Participation Skill}

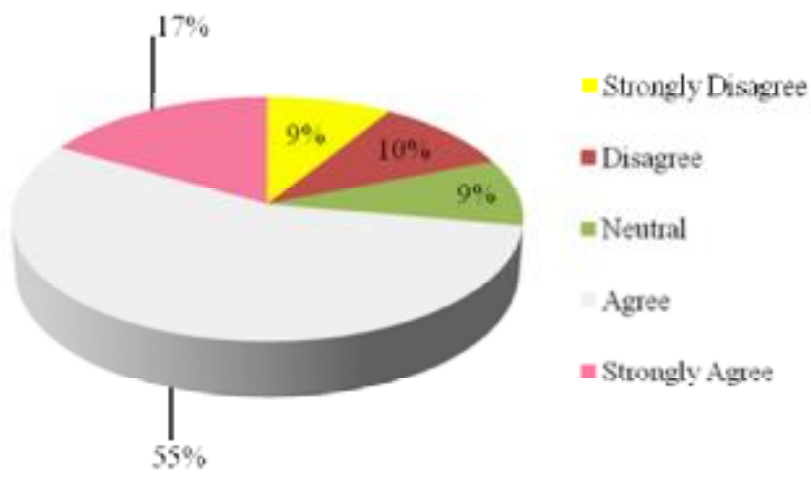

Figure 5. indicates respondents' level of agreement and disagreement for Project participation Skill

Figure, 5 shows agreement and disagreement level for project participation skill that industrial internships develop project participation skill of engineering students during industrial internships.

\section{Discussion}

The results of this study reported that industrial internships contribute to develop oral communication skills of engineering students. This is because during internships engineering students perform various oral communication tasks such as oral presentations, meetings, discussions, conversations, and project participations. All these communication tasks involve oral communication; therefore, they develop oral communication skill of engineering students. As an intern engineering students have to report to supervisor or manager regarding the work they have to perform and the barriers they confront to perform that task. This daily reporting and presentation of ideas increase oral presentation skill of engineering students. In an Irish study $78 \%$ engineers stated that they were required to perform oral presentations on regular basis (Keane, 1999). Meetings are part of workplace communication, and almost all major organizations observe meetings regularly. Although interns observe meetings with supervisor or manager in small settings but these frequent interactions and communications develop oral communication skill of engineering students. Internships develop communication such as oral communication skills (Ellis, 2000; Mihail, 2006) of engineering students. Engineering students discuss work related problems with supervisors or managers at workplace. This is because frequent technical problems occur and engineering students as interns discuss these problems with supervisors or managers. As a result, they develop oral communication skills due to frequent discussions and exchange of ideas and communications. Conversation is a common mode of workplace communication and it does not require any special room or environment. Thus; conversations with coworkers, supervisor and managers develops oral communication skill of engineering students. Woodilla (1993) illustrated that conversations develops better work relationship. Moreover, project participation also increases oral communication skill of engineering students, because engineering students provide valuable suggestions to project members in order to improve project design and its performance. The results of this study are in line with a study conducted by Renganathan Sumathi et al. (2012) on "students' perception of industrial internship programme at Universiti Teknologi Petronas Malaysia. The results of this study indicated that $81.4 \%$ respondents revealed that during industrial internships they developed oral communication or presentation skills. 
International Journal of Applied Linguistics \& English Literature

ISSN 2200-3592 (Print), ISSN 2200-3452 (Online)

Vol. 1 No. 2; July 2012

Additionally, engineering organizations tend to hire engineering graduates that possess relevant work experience and this question is frequently asked from engineering graduates during job interviews. Engineering graduates equipped with internship experience are considered potential job candidates compared to those who fall short in this skill training. This is because internships fill gap between classroom knowledge and practical knowledge and make interns well aware about the work they have to perform at workplace. In sum, internships benefits all three stakeholders industry, engineering universities, and engineering students. It is suggested that engineering universities should arrange proper internship placements for engineering students in their respective field of interest prior to joining the workplace. It is further suggested that internships should be made part of engineering curriculum that presently lack in engineering curriculum taught to engineering students. In fact almost all engineering universities of Pakistan have established industrial liaison offices but their job tends to be issuance of recommendation letters to industries for their placement if possible. Industry also should realize its responsibility to accommodate maximum number of engineering students to prepare them better human capital not only for local but global work environment. Thus, if possible industry should provide some stipend to engineering students during internship period of time meet expenditures, since all engineering students cannot afford it. Thus, all three stakeholders should play their due role to prepare engineering students of Pakistan as global engineers and it will assist to overcome increasing unemployment in engineering profession of Pakistan.

\section{Conclusion}

This study investigated impact of industrial internships on oral communication skills of engineering students of Pakistan in terms of oral presentation skill, meeting skill, discussion skill, conversation skill, and project participation skill. Internships provide that knowledge and exposure to engineering students that they cannot gain merely from classroom knowledge. Thus, industrial internships are vital for engineering students before they join the workplace. During internships engineering students try to solve problems that they have to face in the future. Thus, they get an opportunity to discuss work related problems with supervisors and managers. With technical skills engineering students develop oral communication skills because employer surveys indicate that oral communication skill is an important aspect of modern workplace communication. Engineering students should be equipped with effective communication skills because global organizations demand oral communication skills of engineering graduates to run business of organizations productively. Oral communication skills of engineering graduates are considered as an indicator towards success of modern organizations. Graduate poor oral communication skills lead to poor workplace productivity. Thus, employers' are never ready to take this risk and they assess oral communication skills of engineering graduates during job employment interviews. Summing up the discussion it is concluded that industrial internships are important for engineering students to keep them abreast about the skills and knowledge required by modern industry before they join the workplace.

\section{References}

Coco, M. (2000). Internships: A try before you buy arrangement. SAM Advanced Management Journal, 65(2), $41-47$.

Devine, R. L., Linrud, J. K., Miller, R. H., \&Wilson, J. H. (2007). Required internship programs in marketing: Benefits, challenges and determinants of fit. Marketing Education Review, 17(2), 45-52.

Ellis, N., 2000. Developing graduate sales professionals through co-operative education and work placements: a relationship marketing approach. Journal of European Industrial Training 24 (1), 34-42.

Gault, J., Redington, J., \& Schlager, T. (2000). Undergraduate business internships and career success: Are they related? Journal of Marketing Education, 22(1), 45-53.

Keane, A. and Gibson, I.S. (1999). Communication trends in engineering firms: implications for undergraduate engineering courses. International Journal of Engineering Education, 15, (2), 115-121.

Kofoworola (2003). Engineering education in Nigeria: Present learning systems and challenges for the future. Australasian Journal of Engineering Education, online publication 2003-01.http:www.aaee.com.au/journal/2003 Kofoworola 03.pdf

Lam, T., Ching, L. (2006). An exploratory study of an internship program: The case of Hong Kong students. Hospitality Management, 26, 336-351.

Page | 175 


\section{International Journal of Applied Linguistics \& English Literature}

ISSN 2200-3592 (Print), ISSN 2200-3452 (Online)

Vol. 1 No. 2; July 2012

Mihail, D.M. (2006). Internships at Greek universities: an exploratory study. Journal of Workplace Learning, 18 $(1 / 2), 28-41$.

Mohd. N., Mohd Z., Norhisham, K., Aminah, Z. (2009). Assessment of Engineering Students Perception after Industrial Training Placement. European Journal of Social Sciences, 8, 3.

Rick Weible (2009): Are Universities Reaping the Available Benefits Internship Programs Offer?. Journal of Education for Business, 85(2), 59-63.

Singleton, R. A. Jr., \& Straits, B. C. (2005). Approaches to social research. New York, N.Y.: Oxford University Press.

Sumathi R, Zainal, A., Su Li, S. (2012)."Students' Perception of Industrial Internship Programme", Education + Training, 54, 2 -8 .

Theil, G. R., \& Hartley, N. T. (1997). Cooperative education: A natural synergy between business and academia. SAM Advanced Management Journal, 62(3), 19-24.

Woodilla, J. (1998). Workplace Conversations: The Text of Organizing. In D. Grant, T. Keenoy \& C. Oswick (Eds.), Discourse and Organization 31-50. London: Sage. 